\title{
Analysis of Village Tourism Development in Sawahan, Trenggalek Regency, Indonesia: A Sustainable Livelihood Approach
}

\author{
Rita Parmawati ${ }^{1}$, Yusup Saktiawan ${ }^{2}$, Ferik Antyo Agus Wibowo ${ }^{1}$, and \\ Agung Sih Kurnianto ${ }^{3}$ \\ ${ }^{1}$ Postgraduate, Brawijaya University, Malang \\ ${ }^{2}$ Widyagama Husada Health Education Academy, Malang \\ ${ }^{3}$ Faculty of Public Health, Bakti Indonesia University, Cluring, Banyuwangi
}

Corresponding author: ritaparmawati1990@gmail.com

\begin{abstract}
ARTICLE INFO ABSTRACT
Received

02 November 2017

Accepted

14 March 2018

Available online

30 March 2018

Sustainable approach takes into consideration on five aspects in the development of the model, i.e., social, natural, human, physical, and economic. This study aims to find out the development of tourism village based on sustainable livelihood approach. The study was conducted on JulyAugust, 2017 in Sawahan Village, Watulimo Subdistrict, Trenggalek Regency, East Java Province. The assumption is that the sustainable livelihood process has been running in the village. Five types of assets have been observed namely natural, human, financial, social, and physical. Quantitative and qualitative analysis were used to analyses data and information. Regression analysis on testing partial and simultaneous hypotheses were undertaken. The results showed that natural and social assets become the main factors in supporting the development of sustainable livelihood in Sawahan Village. Although it affects as minor condition, the financial, physical, and human asset can significantly influence when in the same condition.
\end{abstract}

Keywords : asset, livelihood, sustainable, and Sawahan

\section{Introduction}

\section{Background}

Tourism is one of the important industrial sectors and has great potential and opportunities to be developed. The development of tourism in developing countries, including Indonesia, is expected to help equalize economic opportunities and hamper villagers to migrate to the city. The development of tourism is also expected to improve economy condition. It can improve the welfare of the surrounding community (Evita, Sirtha and Sunartha, 2012). The development of tourism in Indonesia in recent years has entered into a new form. The new trend of tourism development in Indonesia is rural based tourism model (Triambodo and Damanik, 2015). The development of rural tourism in Indonesia began to emerge in 2007, when the Indonesian government launched the Visit Indonesia program as a promotion effort. From the number of existing villages, as many as 1,902 villages have the potential to be developed as rural tourism that can be developed as a tourist attraction to be visited by tourists, both of foreign and domestic. In 2012 the government built 978 villages through the village development program (Suarthana et al., 2015). Meanwhile, the target of tourism in 2019 amounted to 20 million foreign tourists. Of that number, it is expected that visit the rural tourism as much as 2 million foreign tourists and urban tourism as much as 2.5 million (Sundaryani, 2017). 
Sustainable approach in Trenggalek Regency, East Java Province lays on five aspects in the development of the model, i.e., social, natural, human, physical, and economic. This study aims to find out the development of tourism village based on sustainable livelihood approach. The assumption is that the sustainable livelihood process has been running in the village. Five types of assets have been observed namely natural, human, financial, social, and physical.

\section{Research objective}

This study aims to find out the development of tourism village based on sustainable livelihood approach in Sawahan village on five types of assets namely natural, human, financial, social, and physical.

\section{Literature Review}

The development of tourist village is strongly influenced by the institutional aspect, the object and the tourist attraction, as well as the means of tourism infrastructure (Damayanti, Soeaidy and Ribawanto, 2014). This is due to the three aspects of the development of the tourist village has an important role in improving the service and quality of tourism products. In the institutional development, the need for proper initial planning in determining the proposed programs or activities, especially on the Tourism Awareness Group (Kelompok Sadar Wisata) in order to be able to improve the knowledge and skills through the programs (Damayanti, Soeaidy and Ribawanto, 2014; Prafitri and Damayanti, 2016).

The importance of the role of the tourism sector requires all stakeholders to develop this sector sustainably (Dangi and Jamal, 2016). Tourism also has a negative impact on destinations, local communities, the natural environment, and the economy. Sustainable approach is an approach that takes into consideration five aspects in the development of the model, ie social, natural, human, physical, and economic aspects. These five aspects are an important component in supporting the success of tourism (Parmawati et al., 2012; Suarthana et al., 2015; Dangi and Jamal, 2016).

\section{Methodology}

\section{Research Location and Data Collection}

This research was conducted in Sawahan Village, Watulimo Subdistrict, Trenggalek Regency, East Java Province. The study was conducted from July to August, 2017. Site selection is based on the consideration that Sawahan Village has implemented Community-based Tourism (CBT), where the community is selfsustainingly trying to build, manage, and monitor the existing tourist attraction through the Duren Sari Tourism Awareness Group. The assumption is that the sustainable livelihood process has been running in the village.

Five types of assets were observed, namely natural asset, human asset, financial asset, social asset, and physical asset. Each asset has a different topic of question: i) natural asset $(\mathrm{X} 1)=$ availability of natural resources and disaster threats, ii) human asset (X2) = knowledge level, community skills in work, language, and health condition, iii) financial asset $(\mathrm{X} 3)=$ level of productivity and property ownership, iv) social asset $(\mathrm{X} 4)=$ involvement of tourism, culture, and social life, and v) physical asset (X5) = existence of infrastructure and life support facilities.

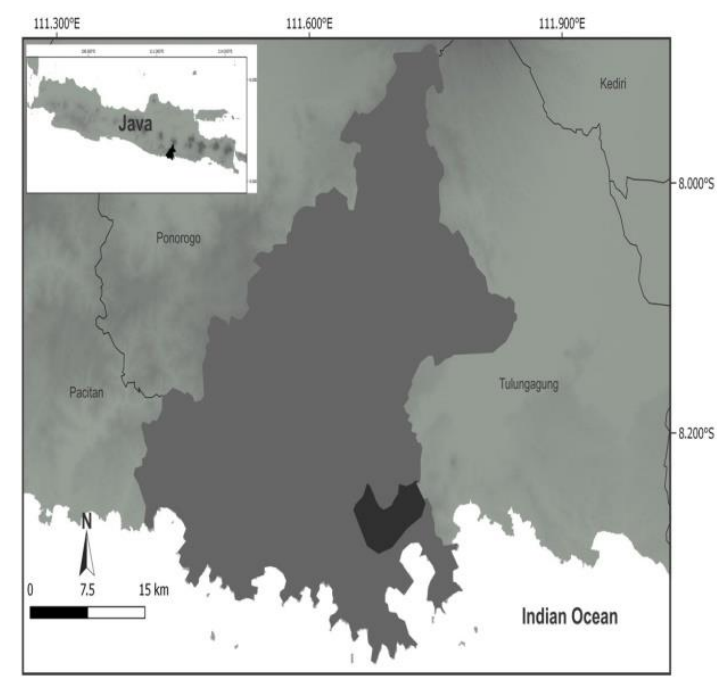

Figure 1. Map of Study Site.

Mark :

Dark grey $=$ Trenggalek Regency;

Black = Sawahan Village, a rural tourism area 
The analysis unit of the respondent is household, male and female, age minimum 20 years, and already working. This study uses the same as 5 to 10 times the number of variable manifest as indicators. This study uses 10 indicators, so the number of respondents is $10 \times 6=60$ respondents. Indicators of this research are tourism village and five assets. Secondary data obtained from the Tourism and Culture Departement, planning, research, and Development Agency, Watulimo District Office, and Sawahan Village Office.

\section{Data Analysis}

Regression analysis on testing partial and simultaneous hypotheses were undertaken. Kolmogorov-Smirnov normality test was used to determine whether the standardized residuals studied were normally distributed. The multicollinearity test was performed using the Variance Inflation Factor (VIF) value. The analysis also used the assumption of homocedasticity (Glejser test) to determine the range of residual values is constant. Autocorrelation was undertaken based on Durbin Watson test to determine correlation between variables (Augusty, 2006).

\section{Result and Discussion}

\section{Kolmogorov-Smirnov Normality Test}

Based on the error normality test with Kolmogorov-smirnov, obtained $\mathrm{p}$ value of 0.778 which is greater than the value of $\alpha$ (0.05) (accept $\left.\mathrm{H}_{0}\right)$ which can be concluded that the error spread normally so that the assumption of normality is confirmed.

Table 1 . Result of One-sample KolmogorovSmirnov Test

One-Sample Kolmogorov-Smirnov Test

\begin{tabular}{llr}
\hline & & \multicolumn{2}{c}{$\begin{array}{c}\text { Unstandardize } \\
\text { Residual }\end{array}$} \\
\hline \multicolumn{1}{c}{$\mathrm{N}$} & & 19 \\
\hline \multirow{2}{*}{ Normal Parameters } & a,b &, 0000000 \\
\cline { 2 - 3 } & $\begin{array}{llr}\text { Mean } \\
\text { Meviation }\end{array}$ & 1,11163499 \\
\hline Most Extreme & Absolute &, 151 \\
\cline { 2 - 3 } Differences & Positive &, 134 \\
\hline
\end{tabular}

http://ojs.unud.ac.id/index.php/eot

\begin{tabular}{lr}
\hline \multicolumn{1}{c}{ Negative } &,- 151 \\
\hline Kolmogorov-Smirnov Z &, 659 \\
\hline Asymp. Sig. (2-tailed) &, 778 \\
\hline a. Test distribution is Normal. & \\
\hline b. Calculated from data. & \\
\hline
\end{tabular}

\section{Multicollinearity Test}

Multicollinearity is a near-perfect linear correlation between two or more predictor variables. Multicollinearity test is used to test whether in the regression model that formed there is perfect correlation or not on predictor variables. The multicollinearity free test is performed using the Variance Inflation Factor (VIF) value. Based on VIF values all predictor variables $(\mathrm{X} 1, \mathrm{X} 2, \mathrm{X} 3$ and $\mathrm{X} 4)$ have VIF value $<10$, then the $\mathrm{H}_{0}$ hypothesis is accepted: there is no multicollinearity between independent variables so that non-multicolinearity assumption is accepted.

Table 2. Result of Multikolinieritas Test

\begin{tabular}{|c|c|c|c|}
\hline \multirow[t]{2}{*}{ Model } & & \multicolumn{2}{|c|}{ Collinearity Statistics } \\
\hline & & Tolerance & VIF \\
\hline \multirow{5}{*}{1} & (Constant) & & \\
\hline & $\mathrm{X} 1$ & ,630 & 1,588 \\
\hline & $\mathrm{X} 2$ & ,441 & 2,269 \\
\hline & $\mathrm{X} 3$ & ,561 & 1,782 \\
\hline & $\mathrm{X} 4$ & 619 & 1,616 \\
\hline
\end{tabular}

\section{Homocedasticity Assumption}

Homocedasticity means that the variety of residual values is constant (fixed). Testing of homocedasticity assumption can be done by Glejser test. Based on the results, it is known that the value of $\mathrm{p}$ predictors $\mathrm{X} 1, \mathrm{X} 2, \mathrm{X} 3$ and $\mathrm{X} 4$ is greater than $\alpha(0.05)$, then the $\mathrm{H}_{0}$ hypothesis is accepted: error has a constant (homogeneous) variable so that nonmulticolinearity assumption is met.

Table 3. Result of Homocedasticity Test

\begin{tabular}{|c|c|c|c|c|c|c|}
\hline \multirow{2}{*}{\multicolumn{2}{|c|}{ Model }} & \multicolumn{2}{|c|}{$\begin{array}{l}\text { Unstandardized } \\
\text { Coefficients }\end{array}$} & \multirow{2}{*}{$\begin{array}{c}\text { Standardi } \\
\text { zed } \\
\text { Coefficie } \\
\text { nts } \\
\text { Beta }\end{array}$} & \multirow[t]{2}{*}{ t-test } & \multirow[t]{2}{*}{ Sig } \\
\hline & & B & Std. Error & & & \\
\hline \multirow{5}{*}{1} & $\begin{array}{l}\text { (Cons } \\
\text { tant }) \\
\end{array}$ & $-14,179$ & 7,311 & & $-1,939$ & ,073 \\
\hline & $\mathrm{X} 1$ & ,259 &, 135 & ,551 & 1,919 & ,076 \\
\hline & $\mathrm{X} 2$ &,- 154 &, 082 &,- 648 & $-1,888$ &, 080 \\
\hline & X3 &, 120 & ,079 & ,460 & 1,511 &, 153 \\
\hline & $\mathrm{X} 4$ & ,194 &, 112 &, 503 & 1,736 & ,105 \\
\hline
\end{tabular}




\section{Non Autocorrelation Assumption}

Autocorrelation is a correlation between a variable value with the same variable in one or more previous lags. The test was performed by using Durbin Watson test. Durbin Watson (D) value was 2,110 and Durbin Watson table with $\mathrm{k}=5, \mathrm{n}=30, \alpha=0.05(5 \%)$ obtained DL value of 0.8588 and DU of 1.8482 .

Table 4. Result of Non-autocorrelation Test

\begin{tabular}{ll}
\hline Durbin Watson Criteria & \multicolumn{1}{c}{ Mark } \\
\hline Less than 0.8588 & Autocorrelation present \\
\hline $0.8588-1.8482$ & No conclusion \\
\hline $1.8482-2.1518$ & $\begin{array}{l}\text { Autocorrelation not } \\
\text { present }\end{array}$ \\
\hline $2.1518-3.1412$ & No conclusion \\
\hline Lebih dari 2.1518 & Autocorrelation present \\
\hline
\end{tabular}

Based on the decision criteria, Durbin Watson (D) 2.115 is between DU and (4-DU) or 1.8482 and 2.1518 in the table, the decision taken is to receive $\mathrm{H}_{0}$, ie no autocorrelation between errors so that non-autocorrelation assumptions are confirmed. According to the result of classical assumption test, it is known that the research data has fulfilled all assumptions, so further regression analysis can be done.

\section{Simultaneous Test Results}

Testing the significance of parameters simultaneously used to determine the effect of predictor variables contained in the regression model to the response variable as a whole or together (see table 5). Testing of significance simultaneously is done using $\mathrm{F}$ test. Based on the test of significance of parameters simultaneously known $\mathrm{p}$ value obtained less than $\alpha(0.05)$, it is decided to accept $\mathrm{H}_{0}$ which means that human, financial, social and physical assets together influencing the development of sustainable livelihood in Sawahan Village. Human, financial, social and physical assets are interrelated and become a consideration for the development of a sustainable livelihood.

http://ojs.unud.ac.id/index.php/eot
Table 5. Significance Parameters for Simultaneous Test

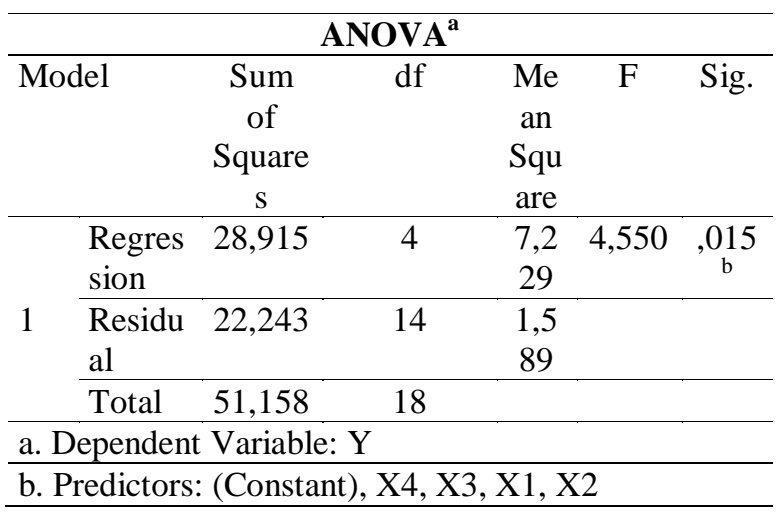

\section{Partial Test Results}

Testing the significance of the parameters of the regression model partially used to determine the influence of each predictor variable to the response variable. Testing is done using $t$ test statistic. Based on the result of the test of significance of individual parameters, it is known that the $2^{\text {nd }}$ regression (second reduction model) obtained from less than $\alpha(0.05)$, it is decided to accept $\mathrm{H}_{0}$, which means that the variable of Finance asset, Social asset and Physical asset significantly influence the development of sustainable livelihood approach of rural tourism in Sawahan Village.

Table 6. Partial Test Results

\begin{tabular}{|c|c|c|c|c|c|}
\hline \multirow[t]{2}{*}{ Mode } & & \multicolumn{2}{|c|}{$\begin{array}{l}\text { Unstandardized } \\
\text { Coefficients }\end{array}$} & \multirow[t]{2}{*}{$\mathrm{t}$ test } & \multirow[t]{2}{*}{ Sig. } \\
\hline & & $\mathrm{B}$ & $\begin{array}{c}\text { Std. } \\
\text { Error }\end{array}$ & & \\
\hline \multirow{5}{*}{1} & $\begin{array}{c}\text { (Consta } \\
\mathrm{nt})\end{array}$ & 18,247 & 14,640 & 1,246 & ,233 \\
\hline & $\mathrm{X} 1$ &,- 142 & ,270 &,- 523 & ,609 \\
\hline & $\mathrm{X} 2$ &,- 544 & ,164 & $-3,325$ &, 005 \\
\hline & $\mathrm{X} 3$ & ,310 & , 159 & 1,953 &, 071 \\
\hline & $\mathrm{X} 4$ & ,353 & ,224 & 1,574 & ,138 \\
\hline \multirow{4}{*}{2} & $\begin{array}{c}\text { (Consta } \\
\mathrm{nt})\end{array}$ & 11,289 & 5,987 & 1,886 & ,079 \\
\hline & $\mathrm{X} 2$ &,- 586 & , 140 & $-4,196$ & 001 \\
\hline & $\mathrm{X} 3$ & ,336 & , 147 & 2,281 &, 038 \\
\hline & $\mathrm{X} 4$ & ,418 & ,181 & 2,310 &, 036 \\
\hline
\end{tabular}

\section{Conformity Testing Model}

From the analysis results obtained $\mathrm{R}$ square value of 0.565 , meaning that the contribution of data to the model formed by 
$56.5 \%$ and the rest of $43.5 \%$ influenced by other variables outside the study.

Formation of Regression Model as a description of asset development

a. Full Regression Model

Regression Model acquired :

$\mathrm{Y}=18.247-0.142 \mathrm{X} 1-0.544 \mathrm{X} 2+$ $0.310 \mathrm{X} 3+0.353 \mathrm{X} 5+e_{i}$

$\mathrm{Y}=18.247-0.142$ Human Asset 0.544 Financial Asset +0.310 Social Asset +0.353 Physical Asset $+e_{i}$

\section{b. First Regression Reduction Model \\ Regression Model acquired : \\ $\mathrm{Y}=11.289-0.586 \mathrm{X} 2+0.336 \mathrm{X} 3+$ $0.418 \mathrm{X} 4+e_{i}$ \\ $\mathrm{Y}=11.289-0.586$ Financial Asset + 0.336 Social Asset+ 0.418 Physical Asset+ $e_{i}$}

Based on the model $\mathrm{b}$, it is known that the regression coefficient of financial asset predictor variable is -0.586 , that is, if other predictor variables are fixed and financial asset increases by 1 unit. This illustrates the development of a sustainable livelihood in Sawahan Village decreased by $58.6 \%$. The regression coefficient of social asset predictor variable is 0.336 . This illustrates another predictor variable of fixed value and social asset increased by 1 unit, or the development of sustainable livelihood-based tourism village in Sawahan Village increased by $33.6 \%$. The regression coefficient of physical asset predictor variable is 0.418 . This explains if other predictor variables are fixed and physical asset increases by 1 unit, so the development of sustainable-livelihood in Sawahan increased by $41.8 \%$.

The regression model shows the actual position and influence of the observed assets. Independently with the assumption of other asset is fixed, financial asset will actually reduce the development of sustainable livelihood in Sawahan Village by $58.6 \%$. This illustrates the early work of the Sawahan community who are closely related to their property in the form of livestock and land. The absence of tourism developments will soon make them return to their old jobs as farmers, and not to sustainable livelihood. Social asset

http://ojs.unud.ac.id/index.php/eot illustrates the positive trend, which if assumed other asset stability, it will have a positive effect on sustaibale livelihood of $33.6 \%$. In addition, the same condition is illustrated by the physical asset model, which will affect $41.8 \%$ increase in sustainable livelihood.

Social life also greatly influences the sustainability of tourism in the context of the rural tourism (Figure 2). In addition to being a tourist attraction, social structure becomes part in the management of rural tourism conducted in the Sawahan Village. The social structure is known to be an original part of a rural tourism, as happened in Wae Rebo Village, Flores (Louis, 2015), Kampung Naga, Tasikmalaya (Qodariah and Armiyati, 2013). Therefore, sustainable livelihood must rely on the social assets within the village itself.

Although not a major influence, but other asset parameters also have a considerable influence together. The value of the test of parameter significance (tables $5 \&$ 6) indicates a correlation between human, financial, social, and physical assets that occurs jointly. This correlation shows the modalities are interrelated and become a consideration in the development of sustainable livelihood in Sawahan Village. Human resources have a great influence on the development of a tourism. This asset is related to human ability and intelligence in understanding and facing problems in seeing tourism, both in social structure, conservation, and business (Qodariah and Armiyati, 2013; Putri, Soemarno and Hakim, 2015; Haryati et al., 2016). The value of financial and physical assets in the village of Sawahan became a supporting factor. Most societies have possessions that contribute greatly to their economies, such as livestock and land. In addition, village infrastructure has been developed adequately. Infrastructure generally supports the growth and development of tourism.

\section{Variable Mapping}

Based on the variable mapping (Figure 2), a preference of natural and social assets influences the sustainability of a tourist village. Sawahan Village natural resources are considered quite complete and have the strength to survive as a tourist attraction. 
These resources are beaches, seas, and forests. Very little impact of natural disasters also enlarge the value of natural asset as the main carrying capacity of sustainable livelihood.

Community support in the formation of tourist villages has a major impact on sustainable livelihood. Public confidence in the potential of ecotourism as an employment opportunity is also very supportive of sustainable livelihood. This is greater than any other assets, such as a financial asset, in which one of the shares is ownership of property, whether in the form of land or livestock. It also illustrates that tourism opens new opportunities as the main job, replacing other conventional workers in Sawahan Village.

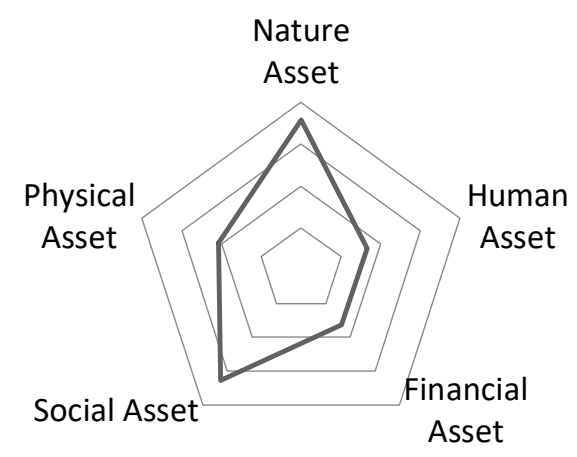

Figure 2. Mapping of Sustainable Livelihood on the Five Assets in the village sawahan.

Sawahan Village becomes a figure of a developing tourist village. The tourist village has a special display that will depict a tourism focus, eg religious village tours, ancient villages with custom architecture, villages with agriculture areas, or villages with social life forms perhaps the only one in the world (Veselinović, Ševarlić and Todorović, 2007; Louis, 2015; Meidiana, Surjono and Saputra, 2015). Objectively, the selected assets have illustrated the form of sustainable livelihood in Sawahan Village, where based on the R square value, it has been shown that $56.5 \%$ indicates a real effect. Nature, in this case is the view of the shape of the earth and the ecosystem in it is the main asset of a tourism-based scenery or ecotourism and support the lifes of people in it (De Wit et al., 2009; Brandl et al., 2017). Nature damage is a part that must be avoided to maintain the sustainability of a tourism. A tourism development can reach a saturation point, where the peak of tourist arrivals that are not followed by conservation awareness will degrade the process back to a minimum. This process can be induced by environmental biophysical changes and inadequate facilities. Peak visits that exceed the comfort limit will soon induce a decrease in tourist traffic (Prasetyowati, Harahab and Soemarno, 2014; Perkins and Debbage, 2016). Sawahan Village describes an early awareness of this problem. Variable mapping (figure 2) shows the community has understood the importance of natural asset in a sustainable tourism. This evidence provides a good foundation for management that is oriented towards nature and human development, and not to profit (Putri, Soemarno and Hakim, 2015). The same fact has been proven that tourism management, which is focused on saving nature, will support the sustainability of ecosystems, community employment, and visits (Putri, Soemarno and Hakim, 2015; Haryati et al., 2016).

\section{Conclusion}

Natural and social asset become the main factors in supporting the development of sustainable livelihood in Sawahan Village. Although it affects as minor condition, the financial, physical, and human asset can significantly influence when in the same condition.

\section{Acknowledgement}

Authors thank to Sawahan Village Chief for research permission and his assistance in the field. Authors also thank to Tourism Awareness Group Duren Sari for a warm assistance during the field, including data collection and sharing.

\section{References}

Augusty, F. (2006) 'Metode Penelitian Manajemen: Pedoman Penelitian Untuk Penulisan Skripsi, Tesis dan Disertasi Ilmu Manajemen', Program Magister Manajemen Fakultas Ekonomi, Universitas Diponegoro, Semarang. 
Brandl, K. et al. (2017) Sustainable Tourism mand Nature Conservation: An Investment in Our Future. Available at: http://surf-nature.eu (Accessed: 2 October 2017).

Damayanti, E., Soeaidy, M. S. and Ribawanto, H. (2014) 'Strategi Capacity Building Pemerintah Desa dalam Pengembangan Potensi Kampoeng Ekowisata Berbasis Masyarakat Lokal', Jurnal Administrasi Publik, 2(3), pp. 464-470.

Dangi, T. B. and Jamal, T. (2016) 'An integrated approach to "sustainable community-based tourism", Sustainability. Multidisciplinary Digital Publishing Institute, 8(5), p. 475.

Evita, R., Sirtha, I. N. and Sunartha, I. N. (2012) 'Dampak perkembangan pembangunan sarana akomodasi wisata terhadap pariwisata berkelanjutan di bali', Jurnal Ilmiah Pariwisata. Denpasar: Universities Udayana.(16 Juni 2014, 6 : 05 PM).

Haryati, J. R. et al. (2016) 'Action Plan ini Developing Sea Turtle Conservationas Ecotourism Attraction in Sukamade, Meru Betiri National Park', Journal of Indonesian Tourism and Development Studies, 4(2), pp. 67-74.

Louis, M. (2015) 'Fungsi Dan Makna Ruang Pada Rumah Adat Mbaru Niang Wae Rebo', Intra, 3(2), pp. 580-585.

Meidiana, C., Surjono, S. and Saputra, A. A. (2015) 'Vitality of Giri Kedaton Site as a Religious Tourism Attraction in Sidomukti Village, Kebomas, Gresik', Journal of Indonesian Tourism and Development Studies. Brawijaya University, 3(3).

Parmawati, R. et al. (2012) 'Level of Sustainable Livelihood Approach at Central Agriculture City of Batu', Journal of Basic and Applied Scientific Research, 2(6), pp. 5631-5635.
Perkins, D. R. and Debbage, K. G. (2016) 'Weather and tourism: Thermal comfort and zoological park visitor attendance', Atmosphere. Multidisciplinary Digital Publishing Institute, 7(3), p. 44.

Prafitri, G. R. and Damayanti, M. (2016) 'Kapasitas Kelembagaan Dalam Pengembangan Desa Wisata (Studi Kasus: Desa Wisata Ketenger, Banyumas)', Jurnal Pengembangan Kota, 4(1), pp. 76-86.

Prasetyowati, A. A., Harahab, N. and Soemarno, S. (2014) 'Tourist Perceptions On Supporting Infrastructure Facilities And Climate-Based Visiting Time Of Ngebel Lake, Ponorogo', Journal of Indonesian Tourism and Development Studies, 2(2), pp. 47-54.

Putri, S. D., Soemarno, S. and Hakim, L. (2015) 'Strategic Management of NatureBased Tourism in Ijen Crater in the Context of Sustainable Tourism Development', Journal of Indonesian Tourism and Development Studies, 3(3), pp. 123-129.

Qodariah, L. and Armiyati, L. (2013) 'NilaiNilai Kearifan Lokal Masyarakat Adat Kampung Naga Sebagai Alternatif Sumber Belajar', SOCIA, 10(1).

Suarthana, I. K. et al. (2015) 'Exploring the community participation, tourism village, and social-economic to environtment impact (case study: Pentingsari Village, Yogyakarta)', International Journal of Business and Management Invention, 4(9), pp. 85-90.

Sundaryani, F. (2017) Target of 15 million tourist arrivals in achievable: minister. Available at: http://www.thejakartapost.com/news/201 7/01/24/target-of-15-million-touristarrivals-is-achievable-minister.html. (Accessed: 30 September 2017). 
Triambodo, S. and Damanik, P. J. (2015)

'Analisis Strategi Penguatan

Kelembagaan Desa Wisata Berbasis

Ekonomi Kreatif (Studi di Desa Wisata

Kerajinan Tenun Dusun Gamplong, Desa

Sumberrahayu, Kecamatan Moyudan, Kabupaten Sleman, DIY)'. Universitas Gadjah Mada.

Veselinović, B., Ševarlić, M. and Todorović, M. (2007) 'Village tourism as generator of rural development in Serbia: Situation and perspectives', in 100th Seminar of the European Association of Agricultural Economists, Thematic Proceedings, pp. 397-402.

De Wit, M. et al. (2009) 'Investing in natural assets. A business case for the environment in the City of Cape Town', Report prepared for the City of Cape Town, Cape Town, South Africa, 18, pp. 294-302. 